\title{
Internal Factors behind the Decline of the Marinid Kingdom
}

\author{
Mohamad Zulfazdlee Abul Hassan Ashari ${ }^{1}$, Ezad Azraai Jamsari ${ }^{1}$, Napisah Karimah Ismail ${ }^{1}$, Nursafira Lubis \\ Safian $^{2} \&$ Zamri Ab Rahman ${ }^{3}$ \\ ${ }^{1}$ Research Centre for of Arabic Language and Islamic Civilization, Faculty of Islamic Studies, Universiti \\ Kebangsaan Malaysia, Selangor, Malaysia \\ ${ }^{2}$ Department of Arabic Language and Literature, Kulliyyah of Islamic Revealed Knowledge and Human Sciences, \\ International Islamic University of Malaysia, Kuala Lumpur, Malaysia \\ ${ }^{3}$ The Armed Forces Religious Corps, Malaysian Armed Forces Headquarters, Kuala Lumpur, Malaysia \\ Correspondence: Mohamad Zulfazdlee Abul Hassan Ashari, Research Centre for of Arabic Language and Islamic \\ Civilization, Faculty of Islamic Studies, Universiti Kebangsaan Malaysia, 43600 UKM Bangi, Selangor, Malaysia. \\ Tel: 60-3-8921-5622. E-mail: mozaha@ukm.edu.my; chotadonukm@gmail.com
}

Received: September 14, 2020

doi:10.5539/jpl.v13n4p51
Accepted: October 7, $2020 \quad$ Online Published: October 13, 2020

URL: https://doi.org/10.5539/jpl.v13n4p51

\begin{abstract}
The Marinid Kingdom (1215-1465) was an Islamic government which emerged in the Maghreb during medieval time. Inheriting the rule from the Almohads, the Marinids were regarded as a strong and formidable Islamic government which once ruled the entire Maghreb and parts of al-Andalus at the height of its glory. Not unlike previous Muslim governments, the Marinid Kingdom also faced various problems and went through several conflicts which affected its stability and integrity. In fact the conflicts even caused the demise of the Marinid Kingdom in the year 1465 which saw the emergence of the Wattasids. This article is aimed at determining the internal factors which contributed to the decline of the Marinids which led to its eventual demise. This study employed a method of qualitative approach via historical study and content analysis, in particular using primary and secondary sources which focused on events which led to the demise of the kingdom. Results of this study identified several internal factors which contributed to the weakness and the eventual collapse of the Marinid Kingdom. In the present-day context, it is not impossible that the same factors can cause any Muslim countries, as a sovereign state and nation, to become weak and disintegrate should the government and the people fail to cooperate in matters regarding the stability of the country.
\end{abstract}

Keywords: the Marinids, the Maghreb (al-Maghrib), al-Andalus, governance, military history

\section{Introduction}

The Marinid Kingdom, founded in 1215 as a left wing movement, was opposed to the Almohads (or alMuwahhidun). In fact, the organized military movement succeeded in toppling the Almohads after conquering Marrakesh in the year 1269. The Marinid military was confronted with protracted resistance and various challenges before the Almohads was defeated. However, during that period, the Marinids took the opportunity to organize and strengthen their position, thus enabling them to bask in the glory of being the sole and legitimate ruler of alMaghrib al-Aqsa territory.

During the span of approximately 250 years, the territory was ruled by 26 sultans of the Marinid Dynasty. Briefly, the Marinid rule can be divided into three eras, namely era of establishment and consolidation (1215-1269), glorious golden era (1269-1335) and era of decline and downfall (1358-1465). Most historians such as al-Salawi, Julien and Shatzmiller attributed the glorious golden era of Marinid rule to the rule of Sultan Abu al-Hasan 'Ali (1331-1351) and Sultan Abu 'Inan Faris (1351-1358), and ascribed the demise of the latter as one of the main factors for the instability in administration leading to the weakening of the Marinid Kingdom. Eventually, the Marinids was toppled by the Wattasids (or Banu Wattas), which replaced it. However, the Marinids made their mark in history by their contributions to achievements in Islamic history and civilization of the Maghreb and surrounding territory, namely al-Andalus. In fact, the Marinid age was significant for many renowned figures such as Ibn Marzuq, Ibn al-Khatib, Ibn Ajurrum, Ibn Batuttah and Ibn Khaldun, which added radiance to the beauty of its history and civilization.

The purpose of this article is to examine the internal factors which contributed to the weaknesses causing the 
downfall of Marinid rule. Overall, this research is a historical study with a qualitative approach using methods of historical study and content analysis of primary kitab (or masdar) and books, focusing on the occurrences leading to the downfall of the Marinids. This research is worth reading because it presents and discusses the factor of some internal weaknesses of Marinid rule. In the context of definition of history, it is not impossible for a present or existing government, to weaken and collapse due to the same factor, if there is no effective cooperation from all parties, both government and citizenry, in handling relevant issues or problems. Therefore, the issue is still on debate. Hence, studies relating to the excellence of contemporary issues in Islamic history and civilization are also assayed by local scholars, covering various issues such as discussion of the role of Akbar (1556-1605) in India unification under the Mughals (Jamsari et al., 2017), the chain of wars according to al-Bidayah wa al-Nihayah by Ibn Kathir al-Dimashqi (Jamsari, Yaacob \& Ashari, 2013), the debate on Islamic history in India in al-Kamil fi alTarikh by Ibn al-Athir (Ashari, Nor \& Jamsari, 2013), as well as the warfare in the history of the Marinid military from the chronicle of al-Salawi (Jamsari et al., 2012).

\section{The Marinid Kingdom}

The Marinids (Banu Marin) was a Muslim Berber kingdom which once existed and controlled present day Morocco. Originated from the Berber Banu Zenata, the kingdom lasted for a period of two and a half centuries from 1215 until 1465. According to Ibn Khaldun (1968), the Marinids were genealogically a branch of Banu Wasin descendants. This can be observed from their ancestral lineage which was Banu Marin ibn (son of) Wartajin ibn Makhukh ibn Judayj ibn Fatin ibn Yaddar ibn Yakhfit ibn 'Abd Allah ibn Wartanbis ibn al-Mu'iz ibn Ibrahim ibn Sahik ibn Wasin. The Marinids had blood relation with Banu Yalumi and Madyunah. Harakat and al-Hariri wrote an excerpt from the book al-Dhakhirah al-Saniyyah, authored by Ibn Abi Zar' al-Fasi, which stated that the Banu Marin were direct descendants of the Zenata Berber tribe who in turn were descendants of the Mudar Arab tribe according to this genealogy: Marin ibn Wartajin ibn Makhukh ibn Judayj ibn Fatin ibn Badr ibn Yakhfit ibn Yaslitin ibn 'Abd Allah ibn Wuratib ibn al-Mu'az ibn Ibrahim ibn Sujayh ibn Wasin ibn Yaslatin ibn Masra ibn Zakiya ibn Sayyid ibn Zanat ibn Jana ibn Yahya ibn Tamriyat ibn Durays ibn Rajih ibn Madaghis ibn Birr ibn Qays 'Ilan ibn Mudar ibn Nazar ibn Mu'ad ibn ‘Adnan (Harakat, 1984; al-Hariri, 1987).

Ibn al-Ahmar (1991) stated that Banu Marin was the noblest clan among those in the Zenata Berber tribe. Other clans in the tribe included Banu 'Abd al-Wad (also known as Banu Zayyan), Banu Maghrawah, Banu Yafran, Banu Tujin, Banu Zawaghah, Banu Fatin, Banu Maghilah, Banu Matgharah, Banu Madyunah, Banu Kushatah, Banu Malzuzah, Banu Matmatah, Banu Walihasah, Banu Luwatah, Banu Marnisah, Banu Damr, Banu Nufusah, Banu Yasunah, Banu Yajbash, Banu Batawiyyah, Banu Kizanayah, Banu 'Ash'ashah, Banu Nafzah, Banu Jarawah, Banu Limayah, Banu Mustarah, Banu Zahilah, Banu Wasin, Banu Sumatah and Banu Tajirah.

A number of historians have studied Banu Marin and traced their ancestral lineage to Amir al-Mu'minin 'Ali ibn Abi Talib. This can be seen in the nasab of the Marinids founder who was 'Abd al-Haqq ibn Mahyu ibn Abi Bakr ibn Hamamah ibn Zayyan ibn Muhammad ibn Muhammad ibn 'Ali ibn Tashufin ibn Yahya ibn 'Ali ibn Ibrahim ibn Isma'il ibn 'Umar ibn al-Hasan ibn 'Ali ibn Abi Talib (al-Hariri, 1987; Ibn al-Ahmar, 1991). This opinion is however disputed by some other historians who asserted that the nasab of Banu Marin coincided with the Prophet Muhammad SAW at Mudar from the descendants of 'Adnan. The latter opinion is taken up by majority of the historians and expert genealogists (al-Hariri, 1987). It is probable that the opinions which linked Banu Marin to 'Ali ibn Abi Talib were purposely fabricated to elevate the status and nobility of Banu Marin among the Zenata Berbers.

The involvement of the Marinids in politics has been ascertained by historians to start in the year of 1195 when they aided the Almohads in the Battle of Alarcos in al-Andalus (Shatzmiller, 1991). Their involvement became more apparent in the years 1213 to 1215 when they opposed the Almohads. Led by 'Abd al-Haqq ibn Mahyu at that time, the Marinids frequently attacked the Almohads dynasty. Consequently, the Almohad dynasty became weakened and several territories in the Maghreb were conquered by the Marinids, among them were Meknes in the year of 1245, Fez (1248) dan Sijilmasah (1255). The Marinids opposition against the Almohads eventually succeeded when the former finally captured the latter's administrative capital, Marrakech in 1269 (Shatzmiller, 1991). The capture of Marrakech once and for all obliterated the Almohads and established the Marinids as the new ruler of the Maghreb.

There were 26 Marinid sultans from the same ancestry. The credibility and powerful thinking of their rulers had made the Marinid kingdom a regional power in Northern Africa even though there were rivalry posed by neighboring kingdoms of the Zayyanids and the Hafsids who were centered in Tilimsan and Tunis, respectively. The Marinids power strengthening and consolidation continued until they reached their era of glory under the ruling of Sultan Abu al-Hasan 'Ali (1331-1351). His reign witnessed the greatness of the Marinids achieving 
excellence in various fields including politics, economy, and the social field. It was during his rule that the Marinids achieved a political mileage when they succeeded in aiding the Nasrids against threats posed by the Christian Kingdom of Castile from northern Iberian Peninsula. In addition to that, the Marinids spread their power over the Zayyanids and the Hafsids when they took over Tilimsan in 1337 and Tunis in 1347 (Shatzmiller, 1991). Economic, social and intellectual progress was rapid during the Marinid era. Artistic and architectural activities flourished in the Maghrib resulting in the construction of numerous mosques, madrasahs and al-zawaya (Harakat, 1984). The following is a list of rulers of the Marinid Kingdom (al-Hariri, 1987; Shatzmiller, 1991; Bik \& Mahmud, 1980; Bosworth, 2004):

- $\quad$ Abu Muhammad 'Abd al-Haqq ibn Mahyu (612-614/1215-1217)

- $\quad$ Abu Sa'id 'Uthman ibn 'Abd al-Haqq (614-638/1217-1240)

- Abu Ma'ruf Muhammad ibn 'Abd al-Haqq (638-642 /1240-1244)

- Abu Yahya Abu Bakr ibn 'Abd al-Haqq (642-656/1244-1258)

- Abu Yusuf Ya'qub ibn 'Abd al-Haqq (656-685/1258-1286)

- $\quad$ Abu Ya'qub Yusuf ibn Ya'qub (685-706/1286-1307)

- $\quad$ Abu Thabit 'Amir ibn Yusuf (706-708/1307-1308)

- $\quad$ Abu al-Rabi` Sulayman ibn Yusuf (708-710/1308-1310)

- Abu Sa'id 'Uthman ibn Ya'qub (710-731/1310-1331)

- Abu al-Hasan 'Ali ibn 'Uthman (731-751/1331-1351)

- $\quad$ Abu 'Inan Faris ibn ‘Ali (751-759/1351-1358)

- Abu Zayyan Muhammad II ibn Faris (759/1358), (763-767/1362-1366)

- Abu Yahya Abu Bakr ibn Faris (759/1358)

- Abu Salim Ibrahim ibn 'Ali (760-762/1359-1361)

- Abu 'Umar Tashufin ibn ‘Ali (762-763/1361-1362)

- Abu Faris al-Mustansir 'Abd al-Aziz ibn 'Ali (767-774/1366-1372)

- Abu Zayyan Muhammad III ibn ‘Abd al-'Aziz (774-775/1372-1373)

- Abu al-'Abbas Ahmad I ibn Ibrahim (775-785/1373-1384)

- $\quad$ Abu Faris Musa ibn Faris (785-788/1384-1386)

- $\quad$ Abu Zayyan Muhammad IV ibn Ahmad (788/1386)

- $\quad$ Abu Zayyan Muhammad V ibn 'Ali (788-789/1386-1387)

- $\quad$ Abu al-“Abbas Ahmad II ibn Ahmad I (789-796/1387-1393)

- $\quad$ Abu Faris ‘Abd al-Aziz ibn Ahmad II (796-799/1393-1397)

- $\quad$ Abu 'Amr 'Abd Allah ibn Ahmad II (799-800/1397-1398)

- $\quad$ Abu Sa'id 'Uthman III ibn Ahmad II (800-823/1398-1420)

- $\quad$ Abu Muhammad 'Abd al-Haqq II ibn ‘Uthman III (823-869/1420-1465)

The Marinid era can be divided into three periods: establishment and consolidation period, golden era and decline and downfall era. The establishment and consolidation era started when 'Abd al-Haqq ibn Mahyu was in power until the downfall of the Almohads in Marrakech (1213-1269). This was followed by the golden era which lasted until the time of Abu 'Inan Faris ruling (1269-1358) while the era of decline started after the demise of Abu 'Inan Faris in 1358 until the collapse of the Marinid Kingdom in 1465.

The era of establishment and consolidation began when Banu Marin started looking for a foothold, power and influence in the Maghreb territory. Their struggle became more prominent when the Almohads were defeated by the Christians in al-Andalus in the Battle of Las Navas de Tolosa in 1212, an event which become the starting point of the Almohads downfall. Throughout 1213 until 1269, the Marinids frequently clashed with the Almohads and managed to grab a few territories in the Maghreb. The Almohads whose fighting power was still not diminished launched in 1217 a counterattack on the Marinids resulting in the defeat of the latter and the death of 'Abd al-Haqq ibn Mahyu (Abun-Nasr, 1987).

The Marinids nevertheless did not give up, rearranged their war strategy and their troops to face the Almohads. 
Efforts to bring down the Almohad dynasty and further the influence of the Marinids in the Maghreb were continued by Marinid rulers after 'Abd al-Haqq. Under the leadership of Abu Yahya Abu Bakr (1244-1258), the Marinids attempted once again to conquer the Maghreb and eventually succeeded in taking control of Meknes away from the Almohads in 1245. The Marinid power grew from strength to strength when Fes, Taza, Sala dan Wadi Umm al-Rabi' were taken from the weakened Almohads in 1248. Between 1250 and 1255, the Marinids gained more territories encompassing Tadla, Sijilmasa and Wadi Dar'. Before the death of Abu Yahya in 1258, the Marinid have almost complete control of the Maghreb except Marrakesh, the capital of the Almohad Kingdom (Abun-Nasr, 1987).

The Marinids' golden era of glory commenced when they managed to topple the Almohad dynasty in Marrakech in 1269, taking over the whole of the Maghreb. Furthermore, moving the administrative capital from Marrakech in the south to Fes in the north of the Maghreb annihilated the influence of the Almohads (Brett \& Frentress, 1996). The Marinids then became the de facto heir of the Almohads even though facing challenges from two other powers of Berber origin namely the Zayyanids and the Hafsids. Nevertheless, majority of historians agreed that the Marinids achieved its era of glory during the reign of Sultan Abu al-Hasan 'Ali (1331-1351). Historical sources of the Maghreb and the Marinids stated that Abu al-Hasan the greatest sultan of the Marinid dynasty (al-Salawi, 1954; Julien, 1970). This is attested by the great achievements of the Marinids during their rule in political, economic, social and military aspects. The Marinids also once managed to spread their control and influence over the entire Maghreb subjugating the Zayyanids and the Hafsids under their protection. This situation continued until the Marinid leadership was taken over by Sultan Abu 'Inan Faris after the death of Abu al-Hasan in 1351.

The Marinids began to decline after the demise of Sultan Abu 'Inan Faris (1351-1358). The kingdom, nevertheless, managed to endure for a further hundred years before its final collapse in 1465. Various conflicts both internal and external inflicted the kingdom such as disputes within the administration, usurping of power, jostling for positions, foreign intervention and threats from outsiders especially from the Christian Castile and Portugal became factors behind the decline and downfall of the Marinids. Eventually, the Marinid Kingdom was wiped out from the Maghreb, replaced by the Wattasids who used to serve the kingdom as viziers (Garcia-Arenal, 1978). Nevertheless, the Marinid Kingdom is still remembered as once a great and powerful Muslim power which used to control the entire Maghreb. Their enormous contribution to the development of Islamic civilization became important source of information in literatures of Islamic history and civilization. In fact, this North African power gave birth to many renowned scholars, among them are Ibn Battutah, Ibn Marzuq and Ibn Khadun, just to name a few.

\section{Downfall of the Marinid Kingdom}

The deterioration of the Marinid power happened after the demise of Sultan Abu 'Inan Faris in 1358. Despite the weakened kingdom, the Marinids endured for about 100 years before being displaced by the Wattasids in 1465 . The decline era from 1358 until 1465 also witnessed the viziers becoming more powerful in the administration of the Marinid Kingdom. In the al-Wuzara' institution, there were positions called the Wizarat Tafwid, a vizier system with absolute power in many matters. This could happen for the sultans were politically weak and relinquished all matters of governing the kingdom to al-Wuzara' (the viziers). This is contradictory to the Marinid glorious era when an institution called Wizarat Tanfidh who were responsible to execute orders of the sultan. This was achievable as the sultans during that time wielded more power concerning governing of the kingdom.

During the decline period of the Marinid Kingdom, the viziers used their powers to strengthen their positions and further their influence and by doing so weakened the powers of the sultan. Ibn Khaldun stated that viziers at that time wielded their powers acting like dictators and at many occasions their powers exceeded that of the sultan's. Among the viziers were al-Hasan al-Fawdudi, 'Umar ibn 'Abd Allah, Abu Bakr ibn Ghazi and Muhammad ibn 'Uthman. The viziers succeeded in placing almost all powers in the administration of the government under their direct control. During this period, the sultan's sovereignty and powers were depleted as the formal hierarchy of administration put the viziers in charge of almost all important matters (al-Hariri, 1987). Even though the domination of viziers in political and administrative affairs was argued to be the factor which contribute to the endurance of the Marinid Kingdom for the 100 years of its declining period, excessive power of the viziers, however, caused government institutions helmed by the sultan to weaken and finally collapsed in 1465 being replaced by the Wattasids, who controlled the viziers institution of the Marinids. There were several factors which led to the deterioration and backwardness of the Marinid Kingdom such as fights for the throne, weak leadership after the death of Sultan Abu 'Inan Faris, excessive powers of the viziers, dwindling spirit of jihad and the involvement of Jews in government administration (Ashari \& Jamsari, 2009).

\subsection{Fighting for the Throne}

This factor is the main factor which jeopardized the stability and the integrity of the Marinid Kingdom and 
consequently became the catalyst to other factors which led to the decline of the kingdom. Fights for the leadership of the Marinids began in the era of Sultan Abu al-Hasan 'Ali when his son, Abu 'Inan Faris wrestled power from the sultan and waged war against Abu al-Hasan to the extent of causing his death in 1351.

This usurp for power was backed by the viziers who lent support to individuals with an interest to become the sultan. This can be seen in the actions of the vizier 'Umar ibn 'Abd Allah who murdered Sultan Abu Salim Ibrahim and replaced him with an intellectually-challenged prince, Abu 'Amr Tashufin. The vizier's role in the murder of the sultan caused many members of the Marinid dynasty proclaimed themselves as the sultan. From the proclamation of Abu 'Inan Faris as sultan in 1348 until the ascension of Abu Sa'id 'Uthman in 1398, there were about 15 members of the Marinid royal family claimed the throne. This was allowed to happen as matters concerning the coronation of the sultan were in the hands of the viziers. If the viziers who supported the individual to become sultan were with less power and influence, the aspiring sultan would ask for supports particularly from tribal leaders of the Berbers and outsiders such as the Nasrid ruler in Grenada (Pennell, 2003).

\subsection{Weak Leadership after the Death of Abu 'Inan}

The declining influence of the Marinid sultans after the death of Sultan Abu 'Inan Faris in 1358 also contributed to the weakness and downfall of the Marinids. The weak power of the sultans over administrative affairs led to viziers having complete authority over almost all government decisions. In addition to this, the weakening of the sultan's power caused foreign intervention in the internal matters of the Marinid Kingdom.

The sultans, due to their weakened position, were merely symbolic, and were frequently forced to succeed one another in a quick succession. Those who gained strong support from the viziers would declare themselves as the ruler, dethroning the current sultan. It can be observed that the sultans during the decline period usually did not rule for more than 10 years. For example, Abu Zayyan Muhammad II (763-767/1362-1368) ruled for only four (4) years and Abu Faris al-Mustansir (767-774/1366-1372) only survived seven (7) years (Bosworth, 2004).

Most of the Marinid rulers during the decline era were not fit to carry the burden and responsibility of government administration. Many of them ascend to the throne at a young age. An example is Sultan Abu Yahya Abu Bakr ibn Faris (759/1358) who were given the bay' $a$ h (oath of allegiance) when he was a child (Harakat, 1984). In addition to this, there was also a sultan who was mentally retarded like Abu 'Amr Tashufin (762-763/1361-1362). His influence and power were so weak to his own defect led a member of the royal family Abu Muhammad 'Abd alHalim ibn 'Umar (763/1362) to declare himself as the ruler in Sijilmasa (Harakat, 1984). The fact that the sultan's power and influence were weak gave opportunities to the viziers to have complete control of the administration and at the same time tighten their grip on their control of the government.

\subsection{Excessive Power of the Viziers}

The death of Sultan Abu 'Inan Faris in 1358 marked the beginning of an era of viziers' excessive control over government matters or known as the era of Wizarat Tawfid. Among the famous Marinid viziers was al-Hasan ibn 'Umar al-Fawdudi. The family of al-Fawdudi was even responsible for replacing the sultan with a member of the royal family. They were responsible for the murder of Abu 'Inan and deliberately caused the son of Abu 'Inan, alSa'id to drown at sea so as to replace the sultan with Abu Zayyan I (Harakat, 1984).

Another example of the vizier's transgression was the action of vizier Sulayman ibn Daud who killed Ibn al-Khatib when he was under the protection of a Marinid Sultan. In addition, vizier 'Umar ibn 'Abd Allah abused his power by appointing Tashufin ibn Abi al-Hasan, a thick-head. When he was dissatisfied with Tashufin, he acted to dethrone Tashufin and put Abu Faris 'Abd al-'Aziz (1366-1372) into the palace. Unfortunately, 'Umar was murdered by 'Abd al-'Aziz because he was worried that 'Umar would betray him (al-Hariri, 1987; Ashari \& Jamsari 2009). The same usurp of power was also seen when the vizier position was held by the Wattasids. The vizier position was used by the Wattasids to strengthen their position in administration frequently using the orders of Sultan 'Abd al-Haqq II to justify their actions. Their grip on power was so immense that when a Wattasid was removed from power, a revolution by the Wattasids against the Sultan erupted which eventually led to the toppling of the Marinid Kingdom in 1465.

\subsection{Dwindling Spirit of the Jihad}

The Marinids carried the call of jihad to al-Andalus as done by the previous administration of the Almoravids and Almohads. The Marinids frequently dispatched troops to join jihad expeditions assisting the Nasrids of Grenada against the Christian north especially the Kingdom of Castile. The first jihad expedition of the Marinid was when the second Nasrid ruler, Muhammad II sent a messenger to the Marinid ruler, Sultan Abu Yusuf Ya'qub (656685/1269-1286) (al-Hariri, 1987). This expedition witnessed a Marinid troop of 5,000 soldiers equipped with 20 battleships crossing the Straits of Gibraltar in 1275. Led by the son of Abu Yusuf, Abu Zayyan, the mission 
captured Tarifa and Algeciras (Jamsari, 2002). Jihad expeditions perpetuated throughout the rule of Abu Yusuf in 1277,1279 and 1285.

Jihad expeditions to al-Andalus were continued during the rule of Sultan Abu al-Hasan 'Ali (731-751/1331-1351). In 1333, the Marinids managed to conquer Gibraltar. Their effort to expel the Christian army from Tarifa, however, failed. In fact, the sultan's son, Abu Malik was even killed in a quick counterattack by the Christians in Jerez in the year 1339 (Abun-Nasr, 1987). In 1340, Abu al-Hasan resolutely crossed the straits to al-Andalus with his family, relatives and entourage to attack the army of the Christians. He himself headed the Marinid Army, flanked by the army of the Nasrids under the leadership of Sultan Abu al-Hajjaj Yusuf ibn al-Ahmar (733-755/1332-1354) heading towards Tarifa to face the Christian army. In that battle famously known as the Battle of Rio Salado, the Muslim army was heavily defeated forcing the Marinid and Nasrid forces to retreat. The Marinids suffered heavy losses as 60,000 soldiers were killed in the battlefield (Harvey, 1990).

The breakdown of the spirit of jihad among the Marinid soldiers was a factor behind the weakness of the Marinid Kingdom. The spirit of jihad began to dwindle after their heavy defeat to the Crusaders in the Battle Rio of Salado in 1340 (Ibn al-Khatib, 2002). Moreover, the fall of Algeciras to the Castile forces in 1344 diminished the influence of the Marinids in al-Andalus. After that, the Marinids no longer sent their troops to al-Andalus and only concentrate their effort to control power over the entire Maghreb.

\subsection{Involvement of the Jews in Administration}

The Jews were given positions in the administration of the Marinid Kingdom especially during the reign of Sultan 'Abd al-Haqq II (1420-1465) who happened to be the last Marinid sultan. Almost all of the Jews lived in Bijayah, Tetuan, Tunis and Fes. They were originally refugees who were expelled from al-Andalus by the Christians in the Reconquest. Even though they were some Jews served the Marinid administration prior to 'Abd al-Haqq II, they were mainly tax collectors and assistants to the viziers who were appointed by the sultan. This changed, however, during the rule of 'Abd al-Haqq II, when he appointed Harun ibn Batash, a Jew, to a vizier position in 1458, sidelining the Wattasids who had been at the helm of the al-Wuzara' institution for many years (Garcia-Arenal, 1978).

The appointment of Harun was controversial among the Marinids. Many allegations surfaced such as control of the Jews on the administration created uneasiness among the Muslims in the Maghreb who had been subjected to the burden of tax payments. The controversy was not helped by the actions of Harun who appointed Jews to hold important administrative positions such as Shawil al-Yahudi as hajib and Husayn al-Yahudi as qa'id al-shurtah. The sultan's nod to the afore-mentioned appointments caused the Wattasids to mobilize a political reformation movement, aided by Shurafa' who mostly were principals or deans of tasawwuf and al-Ribat (religious madrassahs). The reformation movement toppled Sultan'Abd al-Haqq II from power and the Marinids were displaced from power by the Wattasids (Julien, 1970; Garcia-Arenal, 1978).

\section{Conclusion}

The Marinid Kingdom was a Muslim Berber kingdom which once reigned over the Maghreb for two and a half centuries. During their reign much contribution has been made to the advancement of the Islamic civilization especially in the Maghreb region in politics, economy, social progress, intellect, arts and literature as well as in military. Not unlike any other kingdom, the Marinid kingdom too went through a period of decline and eventual downfall. The weakness and downfall of the Marinids were due to several factors which can be categorized as internal and external. The factors which have been mentioned earlier on jeopardized political stability and adversely affected the life and economy of the people then. When the pillar and foundation of the kingdom, namely the sultan and his palace institution, were at stake, the position and influence of the Marinids were also questioned and not taken seriously. This opened up doors for foreign powers to interfere in internal political matters and to launch attacks for strategic territorial gains. The downfall of the Marinid Kingdom in 1465 should serve as a reminder to and taken as a lesson by Muslims societies specifically those Muslim countries. It is not impossible that the same factors which led to the downfall of the Marinids could happen in any Muslim countries which could weaken the position of the country economically and politically. Therefore, all parties must have an awareness and a sense of responsibility in ensuring that the country and its people remain harmonious by having a firm view in and attitude towards all matters concerning Islam and human rights.

\section{Acknowledgement}

This study is financed by the Research Group of Islamic Military History (GUP-2019-027; PP-2018-006), Faculty of Islamic Studies, Universiti Kebangsaan Malaysia. 


\section{References}

Abun-Nasr, J. M. (1987). A History of the Maghrib in the Islamic Period. Cambridge: Cambridge University Press. https://doi.org/10.1017/CBO9780511608100

al-Hariri, M. I. (1987). Tarikh al-Maghrib al-Islam wa al-Andalus fi al-'Asr al-Marini. Kuwait: Dar al-Qalam li al-Nashr wa al-Tawzi‘.

al-Salawi, A. A. K. (1954). Kitab Istiqsa li Akhbar Duwal al-Maghrib al-Aqsa. Eds. al-Nasiri, Ja'far \& Muhammad al-Nasiri. (Vol. 3 \& 4). Cairo: Dar al-Kitab.

Ashari, M. Z. A. H., \& Jamsari, E. A. (2009). Kepentingan kestabilan negara: Iktibar daripada kejatuhan Kerajaan Banu Marin [The importance of national stability: Lessons from the downfall of the Marinid Kingdom]. In. The Proceedings of the National Seminar on Islamic Civilization 2009 (NaSIC'09), pp: 74-85.

Ashari, M. Z. A. H., Nor, M. R. M., \& Jamsari, E. A. (2013). Perbahasan sejarah Islam di India dalam al-Kamil fi al-Tarikh Karya Ibn al-Athir [Debate on Islamic history in India in al-Kamil fi al-Tarikh by Ibn al-Athir]. Islamiyyat: The International Journal of Islamic Studies, 35(2), 35-46, http://ejournal.ukm.my/islamiyyat/article/view/4249/2353

Bik, Z. M. H., \& Mahmud, H. A. (1980). Mu 'jam al-Ansab wa al-Usrat al-Hakimah fi al-Tarikh al-Islami. Beirut: Dar al-Ra'id al-'Arabi.

Bosworth, C. E. (2004). In C. Hillenbrand (Ed.), The New Islamic Dynasties: A Chronological and Genealogical Manual. Edinburgh: Edinburgh University Press Ltd.

Brett, M., \& Fentress, E. (1996). The Berbers (pp. 113). Oxford: Blackwell Publishers Ltd.

Garcia-Arenal, M. (1978). The revolution of Fas in 869/1465 and the death of Sultan 'Abd al-Haqq al-Marini. Bulletin of the School of Oriental and African Studies University of London, 41, 43-66. https://doi.org/10.1017/S0041977X00057773

Harakat, I. (1984). al-Maghrib 'Abr al-Tarikh. Casablanca: Dar al-Rashad al-Hadithah.

Harvey, L. P. (1990). Islamic Spain 1250 to 1500. Chicago: The University of Chicago Press. https://doi.org/10.7208/chicago/9780226227740.001.0001

Ibn al-Ahmar, I. (1991). Rawdat al-Nisrin fi Dawlat Bani Marin. Rabat: al-Matba'at al-Malkiyyah.

Ibn al-Khatib. (2002). Kinasat al-Dukkan ba'da Intiqal al-Sukkan. Port Said: Maktabat al-Thaqafah al-Diniyyah.

Ibn Khaldun, A. (1968). Kitab al- 'Ibar wa Diwan al-Mubtada' wa al-Khabar fi Ayyam al- 'Arab wa al- 'Ajam wa al-Barbar wa man 'Asarahum min Dhawi al-Sultan al-Akbar (7th ed.). Beirut: Dar al-Kitab al-Lubnani.

Jamsari, E. A. (2002). Kerajaan Nasriyyah di Granada: Satu kajian mengenai sumbangan tamadun dan kelangsungan politik kuasa Islam di Andalus [The Nasrids in Grenada: A study on their contribution to Islamic civilization and political continuity in Andalus]. (Unpublished master's thesis). Department of Arabic Studies and Islamic Civilization, Faculty of Islamic Studies, Universiti Kebangsaan Malaysia, Bangi, Selangor.

Jamsari, E. A., Ashari, M. Z. A. H., Kamaruzaman, A. F., \& Sulaiman, A. (2012). Warfare in the history of the Marinid military from the chronicle of al-Salawi. Australian Journal of Basic and Applied Sciences, 6(8), 6573. Retrieved from http://www.ajbasweb.com/old/ajbas/2012/August/65-73.pdf

Jamsari, E. A., Ashari, M. Z. A. H., Nor, M. R. M., Sulaiman, A., Safiai, M. H., Ibrahim, I. A., \& Ahmad, M.Y. (2017). Akbar (1556-1605) and India unification under the Mughals. International Journal of Civil Engineering and Technology, 8(12), 768-781. Retrieved from https://www.iaeme.com/MasterAdmin/uploadfolder/IJCIET_08_12_084/IJCIET_08_12_084.pdf

Jamsari, E. A., Yaacob, S. E., \& Ashari, M. Z. A. H. (2013). Rentetan peperangan dalam kitab al-Bidayah wa alNihayah karya Ibn Kathir al-Dimashqi [The chain of wars according to al-Bidayah wa al-Nihayah by Ibn Kathir al-Dimashqi]. Journal of al-Tamaddun, 8(2), 63-80, https://doi.org/10.22452/JAT.vol8no2.6

Julien, C. A. (1970). History of North Africa: From the Arab Conquest to 1830 (John Petrie, Trans.). London: Routledge \& Kegan Paul Ltd.

Pennell, C. R. (2003). Morocco: From Empire to Independence. Oxford: Oneworld Publications.

Shatzmiller, M. (1991). Marinids. In The Encyclopaedia of Islam (Vol. 6., pp. 571-575). Leiden: E.J. Brill. 


\section{Copyrights}

Copyright for this article is retained by the author(s), with first publication rights granted to the journal.

This is an open-access article distributed under the terms and conditions of the Creative Commons Attribution license (http://creativecommons.org/licenses/by/4.0/). 